\title{
Repression of Press Freedom in Nigerian Democratic Dispensations
}

\author{
Akeem Ayofe Akinwale*
}

\begin{abstract}
The Nigerian socio-political environment influences press freedom with adverse implications for education, information, entertainment and surveillance. A theoretical recognition of the press as the "fourth estate" connotes the capacity of the press to monitor the tiers of government (the legislature, the executive and the judiciary). However, the state monitors the press in Nigeria in a manner that negates the principle of the fourth estate. This article examines the repression of press freedom in Nigerian democratic dispensations. Using questionnaires and indepth interviews, data were drawn from 440 members of staff of selected print and electronic press organisations in Lagos and Oyo states of Nigeria. Results showed that although the press facilitated the development of democracy, challenges to press freedom were frequent. Respondents largely confirmed that the press kept the public informed, entertained and enlightened, and it set standards and established values for public conduct. The findings showed that the proposed Freedom of Information Bill (FIB) would empower the press and promote democracy in Nigeria if passed into law and implemented. Therefore, it was recommended that press organisations should pursue their professionalism and the ethics of journalism rather than succumb to socio-political forces influencing the quantity and quality of information made available to the public. Political leaders in Nigeria should accommodate public opinion and press reports on necessities for socioeconomic development before making any public interest decision.
\end{abstract}

Keywords: media movement, press freedom, public opinion, democracy, development.

\footnotetext{
* Department of Sociology, Landmark University, Omu Aran, Kwara State.
} E-mail: akimascholar@yahoo.com 


\section{Résumé}

L'environnement sociopolitique nigérian influence la liberté de la presse avec des implications adverses pour l'éducation, l'information, le divertissement et la surveillance. Une reconnaissance théorique de la presse comme le «quatrième pouvoir » connote la capacité de celle-ci à surveiller les niveaux de gouvernement (le pouvoir législatif, le pouvoir exécutif et le pouvoir judiciaire). Cependant, l’État au Nigeria surveille la presse d'une manière qui nie le principe de quatrième pouvoir. Cette étude examine la répression de la liberté de la presse dans les dispensations démocratiques nigérianes. Utilisant des questionnaires et des entretiens approfondis, des données ont été obtenues auprès de 440 membres du personnel d'organismes choisis de presse écrite et de presse électronique dans les États de Lagos et d'Oyo au Nigeria. Les résultats ont montré que bien que la presse ait facilité le développement de la démocratie, la liberté de la presse était fréquemment confrontée à des défis. Les répondants ont largement confirmé que la presse continuait d'informer, de divertir et d'éclairer le public, et elle fixait des normes et établissait des valeurs pour le comportement du public. Les résultats ont montré que le Projet de loi sur la liberté d'information - Freedom of Information Bill (FIB) - proposé habiliterait la presse et promouvrait la démocratie au Nigeria s’il est adopté et mis en œuvre. Par conséquent, il a été recommandé que les organismes de presse poursuivent leur professionnalisme et l'éthique du journalisme au lieu de succomber aux forces sociopolitiques qui influencent la quantité et la qualité de l'information fournie au public. Les dirigeants politiques au Nigeria devraient prendre en compte l'opinion publique et les articles de presse sur les besoins de développement socioéconomique, avant de prendre toute décision d'intérêt public.

\section{Introduction}

Press organisations are vibrant and restive institutions which provide platforms for power negotiations in the public space. They set the stage for public discourse on popular issues and enjoy wide readership. The principal features of press organisations include critical independence, democratic constructiveness and commercial viability (Bruns 2008; Oyeleye 2004; Kuper and Kuper 2001). The state's fear of the power of press organisations and their immense contributions to the defence of fundamental human rights often serves as justification for censorship. To what extent have press organisations taken public interest into consideration and what are their contributions to the development of democracy in Nigeria? How has the suspension of the Freedom of Information Bill (FIB) affected press freedom in Nigeria? What are the measures needed to make the FIB become the Freedom of Information Law (FIL) in Nigeria? 
This study addresses the above questions using primary and secondary data. Primary data were gathered through questionnaires and in-depth interviews conducted among 440 members of sixteen press organisations selected from print and electronic media in Lagos and Oyo states respectively. Secondary data were generated from peer-reviewed articles and official documents. This study is pertinent given the importance of a free press in the development of democracy, and the long history of the repression of press freedom in Nigeria. Several attacks, acts of intimidation and arrests of journalists have been reported in Nigeria, a country with probably the most animated media environment in Africa (Tettey 2008). The historical role of the press in Nigeria has oscillated between one of staunch support for national unity and a democratic culture and one of being a vehicle for the propagation of ethnic, religious and sectional interests (Oyeleye 2004).

The press remains a cornerstone of democracy and popular participation worldwide. In his statement on World Press Freedom Day, President George Bush (2008) mentioned that press freedom was enshrined in the first amendment to the United States Constitution, recognising freedom of speech as a necessity for a free society. Similarly, Nigerian governments have made constitutional provision for press freedom. Section 24 (1) of Nigeria's 1960 Constitution states that: 'every person shall be entitled to freedom of expression, including freedom to hold opinions and to receive and impart ideas and information without interference' (Akinola 1998). Also, Section 39 of Nigeria's 1999 Constitution states the right to freedom of expression and of the press (Federal Republic of Nigeria 1999).

The notion that the press is an important factor in the democratic environment (Merrill 1974) has been reflected in the play between the different cultural and ideological forces affecting press freedom in Nigeria. Abati (1998) finds that the prevailing political system in Nigeria determines the scope of press freedom. Conversely, democracy has opened up spaces for the survival of press organisations across the world.

In Africa, the media landscape has shown significant shifts and a tremendous expansion in the number of press organisations as democratic dispensations have replaced dictatorial regimes (Karikari 2004). After the fall of the Saddam Hussein's regime in April 2003, there was remarkable growth in the number and diversity of press organisations in Iraq. Based on in-depth interviews with 22 Iraqi journalists working in the country, Kim and HamaSaeed (2008) found that prior to the Western invasion, press organisations in Iraq had been operating under various government constraints as well as pressures from political parties and religious groups. They also found that terrorists and militants constantly threatened Iraqi journalists. Currently, the 
sustainability of the fledgling Iraqi press organisations depends on the interplay of political turmoil, sectarian violence, and foreign interventions in the country.

As in the Iraqi situation, the transition in Nigeria from military to civilian administration in 1979-1983 and since 1999 resulted in an increase in the number of press organisations. There were two government-controlled television broadcasting stations, fourteen licensed private television stations, eighty-two AM radio stations, thirty-five FM stations and eleven short-wave stations in Nigeria as of 1999 (Hudgens and Trillo 1999).

Symbiotically, democracy depends on effective communication systems channelled through the press (Jacob 2002). However, press organisations which are expected to promote democracy and be promoted by democracy, may also be deployed to protect elite interests to the detriment of the larger society. Against this background, this article is divided into the following sections: the study problem; a brief literature review; an overview of the press situation in Nigeria the study areas; methodology; results; and discussion. The conclusion of this study includes policy implications and recommendations.

\section{The Study Problem}

Nigeria is not yet a free and open society despite the availability of diverse viewpoints flowing from a remarkable abundance of press organisations in the country. However, several press organisations in Nigeria lack complete freedom due to censorship, multiple power centres and volatile political institutions (Agbaje 1992). In spite of the proliferation of press organisations, constitutional provisions for press freedom have not been fully enforced. Military regimes and civilian administrations have in turn violated constitutional rights to press freedom in Nigeria. The sustainability of Nigerian democracy is at stake in the absence of complete press freedom. A political scientist stated that '...democracy is not just about rights. It is equally about participation, interest representation, and contestation' (Aiyede 2000:17). Lack of full recognition for the press is a major political constraint and a constitutional aberration in Nigeria.

Apart from political constraints, other factors have affected the role of the press as the fourth estate. These include commercialization and a decline in the observance by journalists of their professional ethics principally caused by the daily struggle for survival in a highly competitive but limited market (Adjovi 2002; Abati 1998). The danger of repression of press freedom in democratic dispensations is the principal concern of this study. People in a democratic society lacking complete press freedom are at risk of falling victim to violence. Members of the press, especially journalists and editors who struggle against forces that seek to suppress press freedom, have been 
brutalised. Nigeria, China, Cuba and Eritrea were among the countries with high prevalence of arrested and jailed journalists in 2007 (Bush 2008).

Several cases of arrested journalists were reported in Nigeria even during democratic dispensations (The Punch 2008). Generally, state restriction of freedom of expression and police brutality were regular threats to members of the press. Police raided editorial offices and arrested employees of press organisations including the Daily Independent, The News, and The Observer during the 1999-2003 democratic dispensation (The Punch 2008; Onadipe 2002). The police action was said to be the result of press publications considered critical of the Nigerian government. As such, the power of the press to check governance institutions has been curtailed, with grave implications for socio-economic development in Nigeria.

The recent government's refusal to pass FIB into FIL is a current case of repression of press freedom in Nigeria. The FIB sailed through to gain legislative approval but President Olusegun Obasanjo held it up in the period from 1999 to 2007. It was sent back to the legislature during the tenure of President Umar Yar'Adua, (which commenced on 29 May 2007), and has not been given legislative approval. This continued delay in passing the FIB has affected the quality of information made available to the public and has resulted in a decline in public trust in the information published in the press. Scholars have shown that public trust has a tremendous effect on the quality of public administration and a decline in that trust can result in heavy expenditure on the political system (Fard et al. 2007). Other results include increased violation of human rights in Nigeria and an upsurge in rent-seeking activities. This occurs when elites are able to discourage entrenchment of press freedom, thereby preventing the press from reporting their illegitimate dealings which constitute an obstacle to sustainable development in Nigeria.

Unfortunately, elite discourses have captured much of the mediated public sphere in Nigeria. This trend throws up some concern with regard to the marginalisation of the majority of Nigerians. The space allotted to public opinion in the media is so minute that very few people have the opportunity to express their views. Media configuration and their centralization within the contexts of urbanisation and strict gate keeping role of state agents occupied the public spaces needed for public-government partnership (Chan 2005; Bardoes and Haenens 2004; Mitra 2001).

Elite capture of the press-driven public sphere portends danger for democracy as it creates multiple voices that produce different versions of various class interests and exclude the interests of the poor. The economic imperatives behind the operations of many press organisations tend to trump their public service role (Tettey 2008). This situation introduces a dilemma in the understanding of press contributions to the development of Nigerian 
democracy. Painfully, freedom of expression and human rights are in a state of siege in Nigeria, with journalists and their family members routinely arrested, tortured and detained. The Nigerian situation is among the bad cases of press repression in the world.

More journalists were killed worldwide in 2007 than in any year since 1994 (Ellick 2007). Specifically, sixty-four journalists reportedly died in circumstances linked to their work in 2007. Nearly half (thirty-one) of those deaths took place in Iraq, which was ranked as the deadliest country for journalists for the fifth consecutive year. Most of the killings were targeted attacks, as opposed to deaths in crossfire.

In Gambia, recent studies have shown sometimes mortal danger for journalists and a government proclivity for press repression (Jallow 2008; Same 2008). The soldier-turned-civilian President Yahya Jammeh, who seized power in a 1994 bloodless coup d'état, won his third presidential election on 22 September 2006 but his victory has not appreciably moved Gambia closer to a more democratic political culture (Same 2008). In the absence of strong political opposition, the 2006 election resulted in the consolidation of authoritarian rule under democratic government. In light of the above, this study examines press repression in Nigerian democratic dispensations.

\section{Literature Review}

It is broadly agreed that the spread of democracy, advancement of human rights, and the introduction of neoliberal reforms followed the end of the Cold War, although several countries are yet to fully enforce the civil right to press freedom. Few countries have a good record in terms of press freedom and members of the press in many countries including Nigeria are still struggling for full enjoyment of this right. On the global press freedom index, Benin shared almost the same rank as the United Kingdom in 2005 and was ranked highest in Africa (World Bank 2006). The prevalence of free press organisations in Benin was driven by highly motivated local agents of cultural change. Private radio stations driven by cross-fertilization of foreign and indigenous ideas contributed immensely towards the entrenchment of press freedom and promotion of political innovation at the grassroots levels in Benin (Kohnert 2006).

Similarly, community radio stations established in the Democratic Republic of Congo contributed tremendously towards the country's political transition, especially by disseminating necessary information to the public, including the relatively isolated people in conflict areas. Estimates of the impact of private media growth in Madagascar showed that over ninety private radio stations began operations since the late 1990s (Tettey 2008). Private media improved political stability following the hotly contested 2001 presidential 
elections. The significant roles of the press in democracy include periodic civic education, election monitoring, reporting political activities and disseminating election results. Various studies have established the extent to which a vibrant media environment affects citizens' engagement with their political system (Fard et al. 2007; Karppinen 2007; Kuenzi and Lambright 2007; Aiyede 2000). A study of African countries that have held two consecutive multiparty elections since the early 1990s showed a significantly positive relationship between media exposure and voter turnout (Kuenzi and Lambright 2007). Access to vital information affects public discourses and political participation in the society.

The contribution of press organisations to public knowledge has been widely recognised. As a manifestation of their awareness of the East Germans' tactic of mass action against oppressive government, irate citizens of Côte d'Ivoire dislodged General Robert Gueï in October 2000 after he declared himself winner of an election he had in fact lost during the ballot count. The protesters in Côte d'Ivoire emulated the September 2000 popular revolt in Yugoslavia against President Slobodan Milosevic who tried to annul an election in which he was defeated (Onishi 2000). This linkage was demonstrated by an Ivorian student protester's remark: 'The mistake Gueï made was to let us watch scenes from Belgrade' (Bandura 2002:12). In his interpretation of the Côte d'Ivoire situation, Bandura (2002) reasoned as follows:

These macrosocial applications of media ingenuity in translating social cognitive principles into social practice illustrate how a small collective effort can make a huge difference in an urgent global problem... As nations wrestle with the loss of control, the public expresses disillusionment and cynicism over whether their leaders and institutions can work for them to improve their lives (Bandura 2002:13).

Schaffner (2006) demonstrated that citizens' ability to acquire and utilise information about electoral processes would serve as useful instruments of accountability before, during and after elections. Press organisations are supposed to be the most reliable public information sources but circumstances in different countries dictate otherwise. Scholars found that several states in the Middle East had not made significant progress in institutionalising procedural democracy and civil liberties (Spinks et al. 2008). However, they confirmed the liberalisation occurring among monarchies in the region.

Undesirable threats against press freedom in Paraguay attracted global media attention. The Paraguay Union of Journalists described 2007 as a year of struggle, setbacks and advances for the country's journalists, while the International Press Institute stated that journalists who were exposing activities such as corruption also experienced intimidation and death threats 
(Swaffield 2008). Paraguay has been labeled as one of the most troubled democracies in Latin America.

In Chad, six private press organisations protested against a decree which established new infringements and imposed harsh punishments on journalists. They planned to launch a newspaper to denounce government resistance to press freedom (Africa Research Bulletin 2008). Many African states have poor records with regard to civil liberties. Within the context of post-apartheid South African experience, scholars contended that press organisations emerged as autonomous power centres in competition with other power centres (Kriesi 2008; Jacobs 2002). The case of Nigeria is peculiar given its status as the most populous black nation in the world. Nigerian constitutions are elitist as crafted and imposed on civil society by colonial masters, by subsequent military oligarchies and their civilian counterparts (Nwabueze 1997). The elitism of Nigerian constitutions raises questions of illegitimacy and impunity in the violation of civil rights. The next section addresses the extant discourse on the situation of the press in Nigeria.

\section{An Overview of the Press Freedom Situation in Nigeria}

Oyeleye (2004) explored the turbulent relationship between the press, the political process and political actors in the context of the complex structure of Nigerian society. The popularity of press organisations in Nigeria began in 1859 when Henry Townsend established the first known newspaper (Iwe Iroyin) in Abeokuta, Western Nigeria (Abati 1998). In 1863, Robert Campbell established another newspaper (The Anglo-African), which served as a channel for promoting 'the interaction between Britain and Africa' (Dare and Uyo 1996:2). Both newspapers set the stage for the emergence of flourishing indigenous press organisations, with the establishment in 1880 of the Lagos Times and Gold Coast Colony Advertiser by Richard Beale Blaize. The success of the Lagos Times inspired the emergence of several other newspapers. Chief Remi Aboderin established The Punch newspaper in 1973 followed by other publications including National Concord (1980), Business Concord (1982), The Guardian (1983), African Concord (1984), African Economic Digest (1988), Hints (1989), Weekend Concord (1989), Tell (1991), Tempo (1993), The News (1993), P.M News (1994), The Week (1994), This Day (1995), and so on (Abati 1998). The electronic media in Nigeria started up in the 1950s with the establishment of Western Nigeria Television, followed by a proliferation of radio and television stations across the country.

Different press organisations have brought the deplorable state of Nigerian society to public knowledge. They have used critical journalism to expose issues ranging from poverty and crime to bad roads and other shortcomings in Nigerian cities (Ukaegbu 2007). One newspaper vividly captured the plight 
of commuters on a federal road, stating that the hopeless and helpless countenance of Nigerians detained uncomfortably against their will paint a picture of a flock of sheep without a shepherd (Leba 2006). The relationship between the press and Nigerian governments has often been largely antagonistic. It started from mild restrictions of press freedom during the colonial era and grew into full-blown repression in the post-colonial era.

With the establishment of state media and press censorship, the Nigerian press became weak, partisan and ethnocentric. Successive governments employed the press as an instrument of propaganda (Abati 1998). The Nigerian Press Organisation attempted to effect changes in the National Mass Media Commission (NMMC) after the 1999 general elections, but to no avail. The NMMC defines lawful information and balanced reporting in the light of the interests of the state. Similarly, the Newspaper Registration Decree mandates a non-refundable fee of one hundred and fifty thousand naira ( $\$ 150,000$ or $\$ 2,640$ ) for anyone who wants to start a newspaper. In 1984, the Nigerian government published Decree 2, which empowered the Inspector-General of Police to detain indefinitely without trial any person considered as a risk to state security.

Ojo (2006) observed that the government used Decree 60 to establish the Nigerian Press Council (NPC) in 1999 and charged it with the enforcement of professional ethics. Immediately, the Nigerian Union of Journalists (NUJ) and the Newspaper Proprietors Association of Nigeria (NPAN) rejected the creation of the Press Council because the decree contained a number of provisions perceived to be inimical to the operation of a free press. The NPC was empowered to accredit and register journalists. In applying for registration, publishers were expected to submit their mission statements and objectives and could be denied registration if their objectives failed to satisfy the NPC. The penalties for operating without meeting the Council's standard were a fine of $\$ 250,000(\$ 2,500)$ or three years’ imprisonment.

The above review drives home the significance of theory in the discourse of press repression in Nigeria. In any democratic environment, the press can be anchored on three basic theories of responsibility: the libertarian theory, the social responsibility theory and development theory (Abati, 1998). However, John Dewey's theory of the public sphere is suitable for this study given its support for a conceptual model that recognises multiple publics and permeable borders between public and private spheres (Asen 2003). The importance of the theory of public sphere as an antecedent and critical resource for contemporary theorising cannot be ignored. The basic canons of the theory include the role of communication in the formation and reformation of the public sphere. 
A major concern in the social construction of the press communication system is the elite capture of the press. The elites may deploy press organisations as tools for ventilating parochial political interests rather than as a public arena for robust democratic expression. Elite manipulation of press organisations in Nigeria and Madagascar fit the above description. In Madagascar, wealthy people established media organisations and utilised them to articulate their political propaganda (Tettey 2008). In response to elite capture of the private press, religious organisations produced publications to contest for space in Madagascar's public sphere. The Nigerian situation is different in that many religious organisations in Nigeria concentrate more on staging crusades and drawing people closer to God instead of providing parallel media houses.

Striking a balance between competing concerns (public right to know and the necessity of political stability or national security) is a major challenge to press organisations in Nigeria. Similarly, recent situations in Kenya have uncovered the enormity of the dilemma facing press organisations in their attempt to produce balanced reporting. Press organisations in Kenya complied with the Ministry of Information's directive to delay news broadcasts in view of post-election violence and the importance of national security. As a result, these press organisations presented to the public an incomplete picture of socio-political realities in the country (Tettey 2008). Neglect of press freedom can also aggravate national disaster, as demonstrated by experience in South Africa. Danso and Macdonald (2001) asserted that the print media's failure to check the veracity of government statements on immigration in South Africa was partly responsible for some of the worst examples of xenophobic behaviour in that country.

Press contributions to ethno-religious conflict and civil strife in Nigeria cannot be ignored. Nigerians usually patronise different press organisations, which affects their understanding of local and international issues. Also, press organisations serve as sources of socio-economic and other information ranging from advertisements, job opportunities, obituaries, and public events to corporate financial statements and activities of industries in Nigeria.

\section{The Study Areas}

The fieldwork for this study was conducted in different press organisations in Lagos and Oyo States of Nigeria. Specifically, this study's sites were limited to press organisations located in Lagos metropolis and Ibadan, the capital city of Oyo State. Lagos and Ibadan were already large cities prior to the advent of colonial administration in Nigeria. Ibadan emerged as a war camp in 1829 following the settlement of migrant warriors from different locations in southwest Nigeria and became a large empire with a city-state 
(Falola 1984). Lagos State was created through Decree 14 of 1967 during the restructuring of Nigeria into twelve states. Establishment of the University of Ibadan in 1948 enhanced the importance of Ibadan. The concentration of qualified people increased purchasing power in Ibadan and stimulated rapid growth in commerce and in press organisations. However, Ibadan did not succeed in attracting many big industries (Mabogunje 1968:201) whereas Lagos is generally regarded as the commercial capital of Nigeria.

Until 1970, Ibadan was the largest city in sub-Saharan Africa (Lloyd et al. 1967) and Lagos will be one of the five mega-cities in the world by 2015 (Massey 2002). Lagos was the Nigerian Federal Capital Territory from 1967 to 1991 (Obono 2007; Alemika and Chukuma 2005). In the 1980s, the IbadanLagos expressway generated the greatest urban sprawl in Ibadan. Lagos is more cosmopolitan compared to Ibadan. Lagos metropolis comprises fourteen Local Government Areas: Agege, Ajeromi-Ifelodun, Alimosho, Apapa, Ifako-Ijaye, Ikeja, Kosofe, Lagos Island, Lagos Mainland, Mushin, Ojo, Oshodi-Isolo, Shomolu and Surulere (Alemika and Chukwuma 2005). A lagoon divides Lagos State into two geographical areas, the mainland and the island. Obono (2007) succinctly described the basic features of Lagos:

Lagos is characterised by high volumes of immigration, high population densities, a migration induced growth rate of 8 per cent per year, an average household size of seven, poverty, tremendous concentrations of slums and squatter settlements, and a high youth unemployment rate. Lagos is the financial, economic and business capital of Nigeria and West Africa (Obono 2007:32).

Several press organisations were established in Lagos State while very few were set up in Ibadan. Apart from their heterogeneous structure and relevance in Nigerian history, Lagos and Ibadan are areas suitable for this study due to the varied availability of press organisations.

\section{Methodology}

The study population consisted of members of staff of print and electronic media organisations located in Lagos and Oyo states. Four print and four electronic media organisations were chosen in the Ibadan and Lagos metropolitan areas due to their high concentration of press organisations. In all, sixteen press organisations (four newspapers, four magazines, four radio stations and four television stations) were selected while 480 members of the press (240 each from print and electronic media in Lagos and Ibadan respectively) were chosen based on their work schedule, competence, gender, and availability.

Specifically, thirty members of the press were chosen from each of the sixteen selected press organisations. Additionally, one in-depth interview was 
conducted with senior members of staff in each of the sixteen selected press organisations. The sample was drawn from male and female members of staff within different age categories. Participation was restricted to adult members of staff who had spent at least close to five years in their respective organisations. They were considered as having sufficient experience and understanding of the intricacies of press freedom during Nigeria's democratic dispensations. An in-depth interview guide and structured questionnaire were developed for this study. The in-depth interview was structured on the basis of the outcomes of the questionnaire and basic concepts of the theory of press freedom.

This study's questionnaire comprised seventeen open-ended and eighteen focused questions to accommodate different issues including sociodemographic profiles and knowledge of press freedom and its repression during Nigeria's democratic dispensations. The respondents' perception of the emerging Freedom of Information Bill and the extent of their agreement or disagreement with it was tested. The questions were framed with the understanding that democracy promotes press freedom and that press freedom is the cornerstone of democracy. Eight unpaid research assistants drawn from members of staff in the selected press organisations facilitated questionnaire administration to their colleagues.

The research assistants requested at least two weeks to get the answers to the questionnaire back from their colleagues due to their busy schedules. The researcher followed up and monitored the progress of questionnaire administration through regular telephone conversation with research assistants. Considerable response magnitude was obtained from members of the press four weeks after the date the researcher consulted the research assistants and gave them copies of the questionnaire. Only 424 copies of questionnaire were filled and returned against 480 copies originally distributed. Thus, an 88.3 per cent response rate was recorded for this study. All copies of the filled questionnaires were scrutinized for completeness of response and analysed through the application of the Statistical Package for the Social Sciences (SPSS 13). Data obtained from in-depth interviews were analysed ethnographically with the aid of the ZY Index.

\section{Results and Discussion}

Table 1 depicts the respondents' socio-demographic profile. The table shows responsible, mature members of staff by virtue of their marital status, age range (25-60 years) and high level of Western education. Two-thirds (66\%) of the respondents were male and over two-thirds (68.2\%) were married. At least four out of every five respondents (83\%) were Christians and 80.9 per cent had a first degree or Higher National Diploma (HND). The majority 
Table 1: Respondents' Socio-Demographic Profile

\begin{tabular}{|c|c|c|c|}
\hline Profile & Values & Frequency & Percentage (\%) \\
\hline \multirow[t]{3}{*}{ Marital Status } & Not Married & 126 & 29.7 \\
\hline & Cohabitation & 9 & 2.1 \\
\hline & Married & 289 & 68.2 \\
\hline Total & & 424 & 100 \\
\hline \multirow[t]{2}{*}{ Sex } & Female & 144 & 34 \\
\hline & Male & 280 & 66 \\
\hline Total & & 424 & 100 \\
\hline \multirow[t]{2}{*}{ Religion } & Christianity & 352 & 83 \\
\hline & Islam & 72 & 17 \\
\hline Total & & 424 & 100 \\
\hline \multirow[t]{3}{*}{ Education } & ND/NCE/Technical & 18 & 4.2 \\
\hline & First Degree/HND & 343 & 80.9 \\
\hline & Masters & 63 & 14.9 \\
\hline Total & & 424 & 100 \\
\hline \multirow{4}{*}{ Age (Years) } & $<30$ & 63 & 14.9 \\
\hline & $30-39$ & 180 & 42.5 \\
\hline & $40-49$ & 153 & 36.1 \\
\hline & $50+$ & 28 & 66 \\
\hline Total & & 424 & 100 \\
\hline \multirow[t]{6}{*}{ Job Status } & Editor & 126 & 29.7 \\
\hline & Reporter & 216 & 50.9 \\
\hline & Journalist & 18 & 4.2 \\
\hline & Correspondent & 18 & 4.2 \\
\hline & Producer/Presenter & 9 & 2.1 \\
\hline & Newscaster & 37 & 8.7 \\
\hline Total & & 424 & 100 \\
\hline \multirow[t]{3}{*}{ Ethnicity } & Igbo & 36 & 8.5 \\
\hline & Yoruba & 343 & 80.9 \\
\hline & Other & 45 & 10.6 \\
\hline Total & & 424 & 100 \\
\hline \multirow[t]{4}{*}{ Monthly Income (A) } & $<50,000.0$ & 198 & 46.7 \\
\hline & $050,000.00-75,999.00$ & 154 & 36.3 \\
\hline & $76,000.00-100,000.00$ & 54 & 12.7 \\
\hline & $>100,000.00$ & 18 & 4.2 \\
\hline Total & & 424 & 100 \\
\hline \multirow[t]{4}{*}{ Organisation } & Newspaper & 90 & 21.2 \\
\hline & Television & 91 & 21.5 \\
\hline & Radio & 135 & 31.8 \\
\hline & Magazine & 108 & 25.5 \\
\hline Total & & 100 & 424 \\
\hline Working Experience & $<5$ & 162 & 38.2 \\
\hline \multirow{2}{*}{ (Years) } & $5-9$ & 108 & 25.5 \\
\hline & $10+$ & 154 & 36.3 \\
\hline Total & & 424 & 100 \\
\hline
\end{tabular}

Source: 2008 Survey on Repression of Press Freedom in Nigerian Democratic Dispensations 
(61.8\%) had worked in the press organisations under study for over five years whereas their monthly income was relatively low, ranging from $\mathrm{N}$ 40,000 to $76,000.00$ (\$340-\$650) for over 83 per cent of respondents. Over 50 per cent of them were reporters, followed by editors (29.7\%) among others including journalists, correspondents, producers/presenters and newscasters.

\section{Press Freedom in Nigerian Democratic Dispensations}

Table 2 presents the respondents' knowledge of press freedom. Three out of every five respondents (59.6\%) stated that information, education, enlightenment, entertainment and public awareness were the top priorities of their press organisations. Very few (8.5\%) said that advertisements and profit were the top priorities of their press organisations. These divergent views indicate the challenges facing the press with regard to striking a balance between professionalism and public expectations on one hand and on the other hand, keeping the press alive as a business. In their assessment, 42.7 per cent, 34 per cent and 12.7 per cent of the respondents respectively said that inadequate freedom, poor funding, low remuneration, lack of professionalism and corruption were the major problems facing their press organisations.

Over 91 per cent of the respondents confirmed that press freedom was not fully achieved during any democratic dispensation in Nigeria. This finding reflects several reports on harassment of members of the press and human rights abuse in Nigeria. For instance, The Punch (2008) reported that 22 journalists including an American were arrested and detained in Port Harcourt, Rivers State, on the allegation of not obtaining clearance before taking photographs and footage of some facilities at the Shell Petroleum Development Company's gas plant in the Niger Delta. It was recalled that in 2004, the State Security Service raided the office of Insider Weekly, seized some vital documents and arrested some journalists. In September 2007, two German journalists and a US activist were intercepted and detained for two weeks, while four US documentary filmmakers and their Nigerian counterparts were detained for six days in April 2008 (The Punch 2008). Other media houses including The News, Africa Independent Television/ Raypower, Freedom Radio in Kano and Bayelsa Broadcasting Corporation were recent victims of an official clampdown. The editorial section of a popular newspaper in Nigeria observed that:

It is sad that while international standards, which allow journalists to perform their duties without let or hindrance, are respected even at war fronts, Nigerian journalists and media houses face intimidation and harassment on a daily basis at home (The Punch 2008:14). 
Several reasons advanced as evidence of the absence of complete press freedom in Nigeria included restriction on press activity, government refusal to endorse the FIB, censorship, the influence of owners, and harassment of officials of press organisations. All participants in in-depth interviews corroborated the above reasons. They mentioned that lack of press freedom remained a major problem hindering effective contributions of the press to development in Nigeria. More than half of the respondents (55.4\%) considered the public interest as the most important concern for any press organisation whereas 38.2 per cent believed that both state and public interest were paramount.

Some 72.4 per cent felt that their press organisations protected both state and public interests, while only 14.9 per cent maintained that their press organisations protected the public interest. This finding sheds some light on the position of the press as an intermediary between the state and the public. Thus, it can be deduced that press organisations in Nigeria operate between opposite forces (the state and the public). Press organisations face difficulties in the process of maintaining a balance between these forces. One participant uncovered the dilemma of the press in a brief statement: 'the state threatens press organisations, the police harass members of the press and the public does not appreciate the role of the press' (In-depth interview, 18 August 2008).

In the debate concerning the relationship between democracy and the press, an overwhelming majority (87.3\%) strongly believed that the press promoted democracy in Nigeria and 85.1 per cent stated that without the press, the Nigerian democracy would not survive. Only a few respondents (6.4\%) agreed on the co-existence of democracy and the press in Nigeria. By the following frequency of mention (48.8\%, 21.2\%, 15.1\% and 14.9\%), intimidation, restriction of freedom, dangers associated with objective reporting, work hazards and economic hardships came up clearly in the array of risks facing members of press organisations during Nigerian democratic dispensations.

Both awareness and personal experience of hostile relations between Nigerian governments and press organisations were very high at 93.6 per cent respectively. Obviously, governments have succeeded in controlling press organisations in Nigeria, given that more respondents (97.9\%) felt that government opinions were always in the news compared to those (72.4\%) who felt the opinions of ordinary people were always published. Scrutiny of the estimates presented in Table 2 shows that state hegemony, private-public struggles for recognition and reconstruction of press organisations within the context of a neoliberal political economy are separate realities affecting socio-economic development in Nigeria. 
Table 2: Respondents’ Knowledge of Press Freedom

\begin{tabular}{|c|c|c|c|}
\hline Knowledge & Values & Frequency & Percentą \\
\hline Top Priority of the & Edu cation/Information/Enlight enment/ & & \\
\hline \multirow[t]{4}{*}{ Organisation } & En tertainment & 154 & 36.3 \\
\hline & Awareness & 99 & 23.3 \\
\hline & News & 135 & 31.8 \\
\hline & Adverts/Profit & 36 & 8.5 \\
\hline Total & & 424 & 100 \\
\hline \multirow[t]{5}{*}{ Major Problem Facing the Press } & Inadequate Freedom & 181 & 42.7 \\
\hline & Funding/Low Remuneration & 144 & 34 \\
\hline & Self Censorship & 36 & 8.5 \\
\hline & Harassment & 9 & 2.1 \\
\hline & Lack of Professionalism/Corruption & 54 & 12.7 \\
\hline Total & & 424 & 100 \\
\hline Complete Press Freedom during & No & 388 & 91.5 \\
\hline Any Democratic Dispens ation & Yes & 36 & 8.5 \\
\hline Total & & 424 & 100 \\
\hline Reason for Complete or & Govemment Refusal of FIB & 109 & 25.7 \\
\hline \multirow{5}{*}{ Incomplete Press Freed om } & Freedom Restriction & 144 & 34 \\
\hline & Cen sorship/Owner's Influen ce & 81 & 19.1 \\
\hline & Harassment/Persecution of Press Officials & 63 & 14.9 \\
\hline & Anti-Govemment Stories without & & \\
\hline & Media Closure & 27 & 6.4 \\
\hline Total & & 424 & 100 \\
\hline Interest Considered Most & State Interest & 27 & 6.4 \\
\hline \multirow[t]{2}{*}{ Important } & Public Interest & 235 & 55.4 \\
\hline & Both State and Public Interest & 162 & 38.2 \\
\hline Total & & 424 & 100 \\
\hline Interest Protected by Press & State Interest & 54 & 12.7 \\
\hline \multirow{2}{*}{ Organi sation } & Public Interest & 63 & 14.9 \\
\hline & Both State and Public Interest & 307 & 72.4 \\
\hline Total & & 424 & 100 \\
\hline Hierarch y of Relevance between & Democracy Promotes the Press & 54 & 12.7 \\
\hline Democracy and the Press & The Press Promotes Democracy & 370 & 87.3 \\
\hline Total & & 424 & 100 \\
\hline Reason in Support of Democracy & Democracy and the Press Co-Exist & 27 & 6.4 \\
\hline \multirow[t]{2}{*}{ or the Press } & Without Democracy the Press Cann ot Survive & 36 & 8.5 \\
\hline & Without the Press Democracy Cann ot Survive & 361 & 85.1 \\
\hline Total & & 424 & 100 \\
\hline Greatest Risk Facing Members & Danger of Objectivity & 64 & 15.1 \\
\hline \multirow[t]{3}{*}{ of the Press } & Intimidation/Insecurity & 207 & 48.8 \\
\hline & Freedom Restriction & 90 & 21.2 \\
\hline & Hazard/Economic Hard ships & 63 & 14.9 \\
\hline Total & & 424 & 100 \\
\hline Awareness of Problem with Any & No & 27 & 6.4 \\
\hline Member of the Press & Yes & 397 & 93.6 \\
\hline Total & & 424 & 100 \\
\hline Knowledge of Threat if Certain & No & 27 & 6.4 \\
\hline Information is Made Public & Yes & 397 & 93.6 \\
\hline Total & & 424 & 100 \\
\hline Publication of Opinion of & Always & 307 & 72.4 \\
\hline Ordinary People & Occasionally & 117 & 27.6 \\
\hline Total & & 424 & 100 \\
\hline Publication of Opinion of & Always & 415 & 97.9 \\
\hline Govemment or the Elite & Occasionally & 9 & 2.1 \\
\hline Total & & 424 & 100 \\
\hline
\end{tabular}

Source: 2008 Survey on Repression of Press Freedom in Nigerian Democratic Dispensations 


\section{Public Context of FIB and Necessity for FIL in Nigeria}

Table 3 illustrates the respondents' knowledge of the Freedom of Information Bill (FIB) in Nigeria. All the respondents agreed that the FIB should be passed into a Freedom of Information Law (FIL). The majority (87.3\%) endorsed the FIB with highly positive remarks, while the rest (8.5\% and $4.2 \%)$ strongly believed that it would promote press freedom and enhance the development of democracy in Nigeria. Almost half the respondents (46.9\%) believed that there would be easy access to information, while another 34 per cent believed that there would be removal of restrictions on press freedom and media organisations would have greater access to information if the FIB was passed into law. However, the Nigerian government's refusal to steer the FIB into law can be described as a contravention of the Nigerian Constitution, an infringement on human rights and an indictment of President Umaru Yar'Adua, who publicly declared his intention to uphold the rule of law.

In spite of President Yar'Adua's claim that his administration was anchored on the rule of law journalists faced intimidation and harassment in the course of their legitimate duties. In September 2007, a journalist was beaten into a stupor when he covered a prison riot in Ibadan. State Security staff also arrested several journalists in October 2007 for criticising the governors of Borno and Akwa Ibom states (The Punch 2008:14). There was a high level of awareness of the reasons for the delay of the FIB as 68.2 per cent of respondents attributed it to the state attempting to cover up certain government activities and keep them away from public knowledge, 19.1 per cent believed it was due to the government's selfish interest and concern for national security, while 6.4 per cent each claimed that lack of governance transparency, corruption and the state's calls for clarification were the main reasons for the suspension of the FIB.

Apparently, the type of press organisation did not significantly affect the press practitioners' reactions to the FIB, which was generally believed to be necessary for the development of the Nigerian democracy. The press serves society in a various ways, through its political, social, educational and religious functions. The popular reference to the press as the 'fourth estate' points to the capacity of the press to perform the role of a watchdog, monitor those in authority, expose their limitations and provide checks and balances to the three other estates, namely the legislature, the executive and the judiciary. The press helps to keep the public informed, it entertains, educates and sets standards and establishes values for public conduct.

Thus, the press is responsible to the society as an instrument of social order construction (Abati 1998). Unfortunately, there was a lack of consensus on the assurance of when the FIB would become the FIL. While 48.8 per cent thought that the FIB should be passed into law soon, 38.4 per cent said 
that it should be passed immediately and 12.7 per cent noted that it would be passed into law during the next political dispensation. Concerning the principal effect on press organisations of the absence of the FIL, 74.5 per cent of respondents said that its absence had aggravated the traditional restriction of press freedom, followed by 19.1 per cent who believed that the absence of the FIL provided motivation for further struggle for press freedom in Nigeria. With regard to the Nigerian public, 36.1 per cent and 32.1 per cent respectively of respondents felt that the FIL would guarantee public access to right information and easy access to information.

Table 3: The Respondents’ Knowledge of Freedom of Information Bill (FIB)

\begin{tabular}{|c|c|c|c|}
\hline Knowledge & Values & Frequency & Percentage \\
\hline $\begin{array}{l}\text { Perception about } \\
\text { the FIB }\end{array}$ & $\begin{array}{l}\text { Good/Should be Passed into Law } \\
\text { Essential for Democracy } \\
\text { It will Promote Press Freedom }\end{array}$ & $\begin{array}{r}370 \\
18 \\
36\end{array}$ & $\begin{array}{r}87.3 \\
4.2 \\
8.5\end{array}$ \\
\hline Total & & 424 & 100 \\
\hline $\begin{array}{l}\text { FIB Benefit to the } \\
\text { Press if Passed } \\
\text { into Law }\end{array}$ & $\begin{array}{l}\text { Easy Access to Information } \\
\text { Removal of Restriction on Freedom } \\
\text { Eradication of Speculative News } \\
\text { Accountability/Transparency }\end{array}$ & $\begin{array}{r}199 \\
144 \\
54 \\
27 \\
424\end{array}$ & $\begin{array}{c}46.9 \\
34 \\
12.7 \\
6.4 \\
\mathbf{1 0 0}\end{array}$ \\
\hline $\begin{array}{l}\text { Reason for } \\
\text { Government } \\
\text { Refusal of FIB } \\
\text { Total }\end{array}$ & $\begin{array}{l}\text { Fear of Being Exposed/Corruption } \\
\text { Lack of Governance Transparency } \\
\text { Selfish Interest/National Security } \\
\text { Government's Call for Clarification }\end{array}$ & $\begin{array}{r}289 \\
27 \\
81 \\
27 \\
424\end{array}$ & $\begin{array}{r}68.2 \\
6.4 \\
19.1 \\
6.4 \\
\mathbf{1 0 0}\end{array}$ \\
\hline $\begin{array}{l}\text { Thought about } \\
\text { When FIB Should } \\
\text { Be Passed into Law } \\
\text { Total }\end{array}$ & $\begin{array}{l}\text { Immediately } \\
\text { Very Soon } \\
\text { Next Political Dispensation }\end{array}$ & $\begin{array}{r}163 \\
207 \\
54 \\
424\end{array}$ & $\begin{array}{r}38.4 \\
48.8 \\
12.7 \\
100\end{array}$ \\
\hline $\begin{array}{l}\text { Effect of Lack } \\
\text { of Freedom } \\
\text { of Information Law } \\
\text { on the Press } \\
\text { Total }\end{array}$ & $\begin{array}{l}\text { Restriction of Press Freedom } \\
\text { Struggle for Press Freedom } \\
\text { No Serious Effect }\end{array}$ & $\begin{array}{r}316 \\
81 \\
27\end{array}$ & $\begin{array}{r}74.5 \\
19.1 \\
6.4\end{array}$ \\
\hline $\begin{array}{l}\text { Major Advantage } \\
\text { of Freedom } \\
\text { of Information Law } \\
\text { to the Public }\end{array}$ & $\begin{array}{l}\text { Access to Right Information } \\
\text { Easy Access to Information } \\
\text { Accountability/Transparency } \\
\text { Patriotism/High Trust of the Press } \\
\text { Publicly Seen and Heard }\end{array}$ & $\begin{array}{r}153 \\
136 \\
90 \\
36 \\
9\end{array}$ & $\begin{array}{r}36.1 \\
32.1 \\
21.2 \\
8.5 \\
2.1\end{array}$ \\
\hline Total & & 424 & 100 \\
\hline
\end{tabular}

Source: 2008 Survey on Repression of Press Freedom in Nigerian Democratic Dispensations 


\section{Repression of Press Freedom in Nigeria}

Table 4 shows the respondents' knowledge of repression of press freedom in Nigeria. There were no significant differences in the reactions of members of staff of electronic and print media organisations to repression of press freedom in Nigerian democratic dispensations. Two out of every three respondents (68.2\%) were aware of specific policies that created obstacles to press freedom. Such policies included censorship and bureaucracy (37.7\%), decrees and government control of public media (21.8\% each) as well as officially secret and classified information (18.7\%). Respondents recognised the government and police as antagonists of members of press organisations in Nigeria, with their tactics of hindrance, intimidation, harassment and arrest. It is no longer in doubt that the state perceives the press as threat and thus restricts press freedom. Thus, press freedom may remain problematic for as long as the currently dominant class remains in power in Nigeria. Passage of the FIB into the FIL and upgrading the socioeconomic conditions of members of press organisations received massive support from respondents in this study.

Table 4: Respondents' Knowledge of Repression of Press Freedom

\begin{tabular}{|c|c|c|c|}
\hline Knowledge & Values & Frequency & Percentage \\
\hline \multirow{3}{*}{$\begin{array}{l}\text { Awareness of Policy } \\
\text { against Press Freedom } \\
\text { Total }\end{array}$} & No & 135 & 31.8 \\
\hline & Yes & 289 & 68.2 \\
\hline & & 424 & 100 \\
\hline Specified Policy against & Decree(s) & 63 & 21.8 \\
\hline \multirow{3}{*}{ Press Freedom } & Censorship/Bureaucracy & 109 & 37.7 \\
\hline & Official Secret/Classified Information & 54 & 18.7 \\
\hline & Government Control of Public Media & 63 & 21.8 \\
\hline Total & & 289 & 100 \\
\hline Group that Creates Greatest & Government & 370 & 87.3 \\
\hline Problem for the Press & Police & 54 & 12.7 \\
\hline Total & & 424 & 100 \\
\hline Greatest Problem that the & Intimidation/Harassment & 81 & 19.1 \\
\hline Group Can Create for the & Hindrance/Freed om Restriction & 270 & 63.7 \\
\hline \multirow[t]{3}{*}{ Press } & Arrest/Pers ecution & 27 & 6.4 \\
\hline & Unn ecessary Bureaucracy/Secretive & 27 & 6.4 \\
\hline & Refusal of FIB & 19 & 4.5 \\
\hline Total & & 424 & 100 \\
\hline Experience of Waming or & Recently & 127 & 30 \\
\hline Directive not to Publish & Long Time & 144 & 34 \\
\hline Certain Information & Never & 153 & 36.1 \\
\hline Total & & 424 & 100 \\
\hline Measure for Promoting & Passing of FIB in to Law & 343 & 80.9 \\
\hline \multirow[t]{2}{*}{ Press Freedom } & $\begin{array}{l}\text { Passing of FIB in to Law and } \\
\text { Adequate Remu neration }\end{array}$ & 63 & 14.9 \\
\hline & Public Support of the Press & 18 & 4.2 \\
\hline Total & & 424 & 100 \\
\hline
\end{tabular}

Source: 2008 Survey on Repression of Press Freedom in Nigerian Democratic Dispensations 


\section{Conclusion}

Scrutiny of the findings of this study shows that state hegemony, privatepublic struggles for recognition and reconstruction of press organisations within the context of a neo-liberal political economy are separate realities demanding attention in the discourse of public sphere in Africa. The separate realities interlock, as this study has clearly demonstrated. Press organisations have contributed immensely towards the consolidation of democracy in Nigeria whereas the Nigerian socio-political environment has hindered complete press freedom. Constant intimidation and arrest of members of the press is an indication that Nigerian governments lack the political will to address development crises in the country.

Different stories in various media featured public outcries over lack of government transparency and foul play in governance. This study has confirmed that the press kept the public informed, entertained and enlightened, and that it set standards and established values for public conduct. Different press organisations in Nigeria kept the local and international public informed on the remarkable socio-economic news and political developments. Earlier studies confirmed that lack of credibility and the unprofessional conduct of some media organisations could undermine the power of the press (Tettey 2006; Sakr 2003). Some journalists in Africa have been accused of unprofessional conduct such as corruption, chasing spectacular headlines and doctoring reports to attract monetary inducements (Tettey 2008).

This phenomenon is popularly known as white or brown envelope syndrome in Nigeria where some members of press organisations have colluded with government officials principally due to pecuniary motives and the institutionalisation of corruption. The repression of press freedom has remained widespread even in democratic dispensations and may adversely affect the investment climate in Nigeria. If the government remains adamant on holding back the FIB, the public would be denied access to correct information and deprived of the immense benefits that can accrue from transparent governance. This speculation is not unfounded given the fact that many Africans lack knowledge of political processes that affect them due to the extensive opacity of government operations.

A study by Tettey (2008) showed that press organisations assist the public by providing information on various dealings of the government to ensure transparency in governance. Renewed interest in boosting socioeconomic development will not yield positive results until press freedom is entrenched in Nigeria. This pessimism flows from intellectual sensitivity to the flood of current thoughts in global development debates in which the explanatory variables of development have successively moved to institutions 
from the long held beliefs in access to natural resources, physical capital, the acquisition and sustainability of technology, the human capital as well as the generation and implementation of sound policies (Bonger 2006).

To this effect, press organisations in Nigeria require better ways of upholding professional and journalistic ethics rather than succumbing to adverse influences that water down the quality of information needed for sustainable socio-economic development. The Nigerian political class should accommodate public opinion and press reports on the necessity of responsible governance before taking any decision that may be of public interest. The development of Nigeria's democracy largely depends on full recognition of institutional responsibilities - including the role of the press - in nation building. Therefore, practical steps should be taken towards developing the political environment in Nigeria so that electoral malpractices and political terrorism will be drastically reduced or totally eradicated. Additionally, public trust is valuable and should be gained in the movement toward constitutional amendments in Nigeria.

\section{References}

Abati, R., 1998, 'Press Freedom in Nigeria: 1859-1998', in Atere, A.A. and A. Olagbemi, eds., Communication, Language and Culture in Society, Lagos: Bolaji and Associates.

Adjovi, E.V., 2002, 'Liberté de Presse et Corruption au Bénin - la Dérive du Journalisme de Marché', Working Paper No. 10, Mainz University: Department of Anthropology and African Studies.

Africa Research Bulletin, 2008, 'Fight for Press Freedom Political', Social \& Cultural Series, Vol. 45, Issue 3, pp. 17463-17463.

Agbaje, A.A.B., 1992, The Nigerian Press, Hegemony, and the Social Construction of Legitimacy: 1960-1983, Lewiston, NY: The Edwin Mellon Press.

Aiyede, R., 2000, 'The Dynamics of Civil Society and the Democratisation Process in Nigeria', Paper Presented during the Fellowship at the Transregional Center for Democratic Studies (TCDS), New School University, New York, September-December 2000.

Akinola, R., 1998, Nigerian Media and Legal Constraint: Analysis of Press Legislation in Nigeria, Lagos: Centre for Free Speech.

Alemika, E.E.O. and Chukwuma, I.C., 2005, Criminal Victimization and Fear of Crime in Lagos Metropolis, Nigeria, Lagos: CLEEN Foundation.

Asen, R., 2003, 'The Multiple Mr. Dewey: Multiple Publics and Permeable Borders in John Dewey's Theory of The Public Sphere', Argumentation \& Advocacy, Vol. 39, Issue 3, pp. 174-189.

Ayandele, E., 1979, The Educated Elite in the Nigerian Society, Ibadan: University Press. 
Bandura, A., 2002, 'Growing Primacy of Human Agency in Adaptation and Change in the Electronic Era', European Psychologist, Vol. 7, No. 1, pp. 2-16.

Bardoel, J. and d'Haenens, L., 2004, Media Meet the Citizen: Beyond Market Mechanisms and Government Regulations, European Journal of Communication, Vol. 19, No. 2, pp.172.

Bonger, T., 2006, 'Some Thoughts on Socio-Economic Engineering in Fragile States in Africa: The Case of Uganda', Ethiopian Journal of Economics, Vol. 15, No. 2, pp. 51-73.

Bruns, A., 2008, 'Life Beyond the Public Sphere: Towards a Networked Model of Political Deliberation', Information Polity, Vol. 13, pp. 65-79.

Bush, G.W., 2008, 'Statement on World Press Freedom Day', Weekly Compilation of Presidential Documents, 5 May, Vol. 44, Issue 17, pp. 636-637.

Chan, B., 2005, 'Imagining the Homeland: The Internet and Diasporic Discourse of Nationalism', Journal of Communication Inquiry, Vol. 29, No. 4, pp. 336-368.

Dahlgren, P., 2006, 'Doing Citizenship: The Cultural Origins of Civic Agency in the Public Sphere’, European Journal of Cultural Studies, Vol. 9, pp. 272

Danso, R. and McDonald, D., 2001, 'Writing Xenophobia: Immigration and the Print Media in Post-Apartheid South Africa', Africa Today, Vol. 48, No. 3, pp. 132.

Dare, O. and Uyo, A., 1996, Journalism in Nigerian: Issues and Perspectives, Lagos: Nigerian Union of Journalists.

Ellick, A.B., 2007, ‘64 Journalists Killed Worldwide in 2007, Most Since 1994’, New York Times, 18 December, p. 6.

Falola, T. 1984, The Political Economy of a Pre-colonial State: Ibadan, 18301900. Ile-Ife: University of Ile-Ife Press.

Fard, H., Asghar, A. and Rostamy, A., 2007, 'Promoting Public Trust in Public Organizations: Explaining the Role of Public Accountability’, Public Organization Review, Vol. 7, pp. 332.

Federal Republic of Nigeria, 1999, The Constitution of the Federal Republic of Nigeria, Lagos: Daily Times Publications.

Hudgens, J. and Trillo, R., 1999, West Africa: The Rough Guide, 3rd Edition, London: Rough Guides Ltd.

Jacobs, S., 2002, 'How Good is the South African Media for Democracy?', African and Asian Studies, Vol. 1, No. 4, pp. 280-298.

Jallow, A.Y., 2008, 'Press Freedom under Attack in Gambia \& USA, New African, Issue 473, pp. 74-75.

Karikari, K., 2004, 'Press Freedom in Africa', New Economy, Vol. 11, No. 3.

Karppinen, K., 2007, 'Against Naïve Pluralism in Media Politics: On the Implications of the Radical Pluralist Approach to the Public Sphere', Media, Culture and Society, Vol. 29, No. 3, pp. 496.

Kim, H.S. and Hama-Saeed, M., 2008, 'Emerging Media in Peril', Journalism Studies, Vol. 9, Issue 4, pp. 578-594. 
Kohnert, D., 2006, 'Cultures of Innovation of the African Poor: Common Roots, Shared Traits, Joint Prospects? On the Articulation of Multiple Modernities in African Societies and Black Diasporas in Latin America, (http:// mpra.ub.uni-muenchen.de/3704/), 9 August 2008.

Kriesi, H., 2008, 'Political Mobilization, Political Participation and the Power of the Vote', West European Politics, Vol. 31, No. 1, pp. 152.

Kuper, A. and Kuper, J., 2001, 'Serving a New Democracy: Must the Media "Speak Softly”? Learning from South Africa', International Journal of Public Opinion Research, Vol. 13, No. 4, pp. 355-376.

Leba, L., 2006, 'Ore-Benin Road: Metaphor of a Failed Social Contract', Vanguard, Lagos, Nigeria, 23 October.

Lloyd, P.C., Mabogunje, A.L. and Awe, B., 1967, The City of Ibadan, Cambridge: Cambridge University Press.

Mabogunje, A.L., 1968, Urbanization in Nigeria, London: University of London Press.

Massey, D.S., 2002, 'A Brief History of Human Society: The Origin and Role of Emotion in Social Life', American Sociological Review, Vol. 67, No. 1, pp. 1-29.

Merrill, J.C., 1974, The Imperative of Freedom, New York: Hastings House.

Nwabueze, B.O., 1997, 'Decolonizing and Democratizing the Constitution in Africa', Paper presented at The Annual Lecture in Law and Public Policy, University of Ilorin, $15^{\text {th }}$ November.

Obono, O., 2007, ‘A Lagos Thing: Rules and Realities in the Nigerian Megacity’, Georgetown Journal of International Affairs, Summer/Fall, Vol. viii, No. 2, pp. 31-38.

Ojo, E.O., 2006, 'Human Rights and Sustainable Democracy in Nigeria (19992003)', Journal of Social Sciences, Vol. 13, No. 1, pp. 15-29.

Onadipe, A., 2002, 'Nigeria and Democracy: Third Time Lucky?’, Contemporary Review Company Ltd., (www.findarticles.com), 30 March 2008.

Onishi, N., 2000, 'Popular Uprising Ends Junta’s Rule Over Ivory Coast', The New York Times, 26 October, p. A1.

Oyeleye, A., 2004, 'The Mediation of Politicians and the Political Process in Nigeria', Parliamentary Affairs, Vol. 57, No. 1, pp. 157-168.

Sakr, N., 2003, 'Freedom of Expression, Accountability and Development in the Arab Region', Journal of Human Development, Vol. 4, No. 1, pp. 29-46.

Same, A., 2008, ‘The Gambia’s 2006 Presidential Election; Change or Continuity?', African Studies Review, Vol. 51, Issue 1, pp. 59-83.

Schaffner, B., 2006, 'The Political Geography of Campaign Advertising in U.S. House Elections’, Political Geography, Vol. 25, pp. 776.

Spinks, B.T., Sahliyeh, E. and Calfano, B., 2008, 'The Status of Democracy and Human Rights in the Middle East: Does Regime Type Make a Difference?', Democratization, Vol. 15 Issue 2, pp. 321-341.

Swaffield, B.C., 2008, 'Journalists in Paraguay Have Tough Road Ahead', Quill, Vol. 96, Issue 3, pp. 34-34. 
Tettey, W.J., 2008, 'Media Pluralism, Democratic Discourses and Political Accountability in Africa', Paper presented at the Harvard World Bank Workshop, Harvard Kennedy School, 29-31 May 2008.

Tettey, W., 2006, 'The Politics of Media Accountability in Africa: An Examination of Mechanisms and Institutions', The International Communication Gazette, Vol. 68, No. 3, pp. 229-248.

The Punch Editorial, 2008, ‘Arrest of Journalists’, The Punch, 12 September, p.14. Ukaegbu, C.C., 2007, 'Leadership Fatalism and Underdevelopment in Nigeria: Imaginative Policymaking for Human Development', Philosophia Africana, Vol. 10, No. 2, pp.161- 182.

Walton, D., 2007, 'Revitalizing the Public Sphere: The Current System of Discourse and the Need for the Participative Design of Social Action, Systemic Practice and Action' Research, 20, pp. 369-386.

World Bank, 2006, World Development Report 2006: Equity and Development, Washington, D.C.: Oxford University Press. 